\title{
Staðnemar og fjarnemar í grunnskólakennaranámi við Menntavísindasvið: Bakgrunnur, viðhorf og áhugi á að starfa við kennslu
}

\author{
Duríður Jóna Jóhannsdóttir og Amalía Björnsdóttir
}

Abstract $\quad$ Um höfundana About the authors $>$ Heimildir

Minnkandi aðsókn að kennaranámi og skortur á kennurum veldur talsverðum áhyggjum. Fyrir um aldarfjórðungi var farið í átak til að fjölga réttindakennurum en hlutfall leiðbeinenda hafði verið hátt, einkum á landsbyggðinni. Farið var að bjóða upp á fjarnám og samið var við kennaramenntunarstofnanir um að taka við fleiri nemum. Hlutfall leiðbeinenda lækkaði í kjölfarið og einnig varð efnahagshrunið 2008 til pess að kennarar sneru aftur til starfa í grunnskólum. Nú hefur hlutfall leiðbeinenda hækkað að nýju og óttast er að fjöldi útskrifaðra grunnskólakennara með réttindi haldi engan veginn í við pann fjölda sem hættir störfum, meðal annars vegna aldurs. Brottfall úr grunnskólakennaranámi og hæg námsframvinda veldur einnig áhyggjum. Í pessari rannsókn er dregin upp mynd af bakgrunni grunnskólakennaranema við Menntavísindasvið Háskóla Íslands og kannað hvort munur sé á fjar- og staðnemum. Niðurstöður benda til pess að fjarnemar eigi síður háskólamenntaða foreldra en staðnemar og að börn kennara fari frekar í staðnám en fjarnám. Svipað hlutfall fjarnema og staðnema vinnur með námi en fjarnemar vinna mun fleiri tíma á viku. Til að mynda vinna $42 \%$ peirra meira en 30 tíma á viku meðan hið sama á við um 4,5\% staðnema. Рað hvort nemar eru í stað- eða fjarnámi tengist ekki aðdráttarafli kennarastarfsins en hversu ánægðir peir eru með bæði námskeið í uppeldis- og kennslufræði og kennslufræði greina tengist aðdráttaraflinu, og pættir sem tengjast vettvangsnámi skipta miklu máli. Detta er í takt við fyrri rannsóknir um mikilvægi peirrar reynslu sem kennaranemar fá í starfi með námi og í æfingakennslu.

Efnisorđ: Kennaranám, fjarnám, staðnám, aðdráttarafl kennarastarfs, grunnskólakennaranám.

\section{Inngangur}

Minnkandi aðsókn að bæði leik- og grunnskólakennaranámi hefur verið áhyggjuefni á síðustu árum. Í pessari grein er athygli beint að nýliðun í stétt grunnskólakennara og að námi í grunnskólakennarafræðum við Menntavísindasvið Háskóla Íslands par sem stærstur hluti grunnskólakennara á Íslandi er menntaður'.

Nýlegar tölur um hækkandi hlutfall leiðbeinenda í grunnskólum eru vísbending um að kennaraskortur sé pegar farinn að segja til sín (Hagstofa Î́slands, 2018a). Stór hópur menntaðra grunnskólakennara starfar ekki við kennslu (Helgi Eiríkur Eyjólfsson og Stefán Hrafn Jónsson, 2017) og mikilvægt er að vita hvaða pættir í bakgrunni kennaranema og náminu sjálfu tengjast áhuga á kennarastarfinu. Brottfall og hæg námsframvinda hjá grunnskólakennaranemum veldur einnig áhyggjum (Ríkisendurskoðun, 2017).

Háskólinn á Akureyri útskrifaði fyrstu grunnskólakennarana árið 1996 og pangað til kennaranámið var lengt árið 2011 voru að meðaltali 38 grunnskólakennarar brautskráðir á ári. Eftir lenginguna höfðu 50 lokið meistaranámi á árunum 2014-2016 (Bragi Guðmundsson, 2016). Listaháskóli Íslands hefur síðan 2010 starfrækt listkennsludeild sem menntar fólk með grunnmenntun í listum til kennslustarfa í grunn- og framhaldsskólum. 
Í 25 ár hefur verið hægt að stunda grunnskólakennaranám í fjarnámi, eða frá árinu 1993 pegar Kennaraháskóli Íslands hóf að bjóða B.Ed-nám í fjarnámi. Fjarnáminu var komið á fót vegna skorts á menntuðum kennurum, einkum á landsbyggðinni, og var liður í að fjölga réttindakennurum (Lára Stefánsdóttir og Sigurjón Mýrdal, 1993). Fyrstu árin var gert ráð fyrir að fjarnemar tækju námið með vinnu sem leiðbeinendur í grunnskólum og var priggja ára hefðbundið nám pví skipulagt sem fjögurra ára fjarnám.

Ekki er lengur gert ráð fyrir öðru skipulagi fyrir fjarnema en staðnema á Menntavísindasviði, sem varð til pegar Kennaraháskólinn sameinađist Háskóla Íslands árið 2008 (Duríður Jóhannsdóttir og Sólveig Jakobsdóttir, 2011). Nemar geta valið námskeið ýmist í fjarnámi eða staðnámi eftir hentugleikum og eru ekki skráđir á námsleið eftir námsformi. Degar hæg framvinda í kennaranámi er talin vandamál er mikilvægt að kanna hvort munur er á staðnemum og fjarnemum og aðskilja pessa hópa við greiningu. Pá er mikilvægt að finna út að hvaða leyti pessir hópar eru ólíkir, til að mynda hvort og hversu mikið hvor hópur um sig stundar launavinnu með fram námi og pá hvers konar vinnu.

Í upphafi var fjarnám einkum ætlað starfandi leiðbeinendum í grunnskólum og lengi vel var nokkuð hátt hlutfall fjarnema við kennslu. Deir sem eru í peirri stöðu hafa nokkra sérstöðu miðað við aðra kennaranema par sem peir fá æfingu og öðlast praktíska reynslu í starfi sínu með fram háskólanáminu (Duríður Jóhannsdóttir, 2012; Duríður Jóhannsdóttir og Roth, 2014). Mikilvægt er pví að vita hversu stór hluti kennaranemahópsins sinnir kennslu með námi, en eftir að kennaranámið var lengt er nokkuð um pað að nemar, sérstaklega á meistarastigi, séu að kenna. Með pví að átta sig á stöðu og aðstæðum kennaranema ætti að vera hægt að skipuleggja námið betur út frá ólíkum pörfum peirra og meta hvort hópar stað- og fjarnema purfa ólíkan stuðning til að ljúka námi innan eðlilegra tímamarka.

Að síðustu er mikilvægt að kanna hvaða pættir stuðla að pví að gera kennarastarfið eftirsóknarvert fyrir kennaranema, p.e. hvaða pættir eru vísbending um pað hvort nemar eru líklegir til að vilja fara að kenna að loknu námi og hvort peir eru líklegir til að halda áfram í starfinu, en eins áđur var bent á starfar stór hópur menntaðra grunnskólakennara ekki við kennslu (Helgi Eiríkur Eyjólfsson og Stefán Hrafn Jónsson, 2017).

Vorið 2017 var lögð fyrir grunnskólakennaranema á Menntavísindasviði norræn könnun par sem leitast var við að finna út hvaða pættir í kennaranámi, bæði í háskóla- og vettvangsnámi, tengdust líkum á pví að kennaranemar hefðu trú á eigin getu til kennslu og áhuga á að starfa sem kennarar. Höfundar pýddu spurningalistann úr norsku og bættu nokkrum spurningum við íslenska útgáfu hans, meðal annars um vinnu með námi og hvort nemar væru í stað- eða fjarnámi. Greinin er byggð á pessari könnun og sagt er frá niðurstöðum sem varða ólíka stöðu fjar- og staðnema og pað hvaða pættir tengjast skuldbindingu gagnvart kennarastarfinu.

\section{Dörf á nýliðun í stétt grunnskólakennara}

Til að hægt sé að manna störf grunnskólakennara parf að útskrifa nægilega marga til að taka við störfum peirra sem hætta kennslu. Kennaranemar sem útskrifast purfa að vilja hefja starf við kennslu og síðan er mikilvægt að peir vilji halda áfram í starfi. Árið 2008 er ákveðinn vendipunktur í menntun og mönnun kennarastéttarinnar. Dað ár var kennaranám lengt í fimm ár (lög um menntun og ráđningu kennara og skólastjórnenda við leikskóla, grunnskóla og framhaldsskóla nr. 87/2008) og pá varð efnahagshrun á Íslandi sem hafði í för með sér samdrátt á vinnumarkaði sem gerði pað að verkum að menntaðir kennarar, sem höfðu verið við önnur störf, sneru aftur til kennslu.

Helgi Eiríkur Eyjólfsson (2017) rannsakaði grunnskólakennara sem brautskráđust á árunum 2002 til 2012 frá Háskóla Íslands/Kennaraháskólanum og Háskólanum á Akureyri. Niðurstöður leiddu í ljós að 65\% fara að kenna eitthvað innan fimm ára frá útskrift en hefji peir ekki kennslu á pessum fimm árum pá er ólíklegt að peir snúi sér að kennslustörfum. Dar sem rannsóknin nær yfir stutt 
tímabil er erfitt að meta hversu vel kennarar endast í starfi, en 69\% peirra sem hefja kennslu eru að kenna sjö árum seinna. Dátttakendur voru beðnir að meta álag í starfi og niðurstöður sýndu að peir sem starfa við kennslu meta starfsálag meira en peir sem starfa við annað. Grunnskólakennarar telja álag í starfi líka vera meira en fólk telur almennt á vinnumarkaði á Íslandi. Dátttakendur lýstu pví hversu mikilvægt væri að fá stuðning, til dæmis að hafa leiðsagnarkennara (mentor) eða formlegan stuðning skólastjórnenda í byrjun kennsluferils par sem slíkt auki sjálfstiltrú, bæti líðan og dragi úr líkum á að kennarar hverfi úr starfi. Niðurstöður sýna að hætta á brotthvarfi úr starfi eykst um $25 \%$ sé stuðningur ekki til staðar.

Finnskir kennarar endast betur í starfi og íhuga síður að skipta um starf en í flestum öðrum löndum (OECD, 2014). Par er lögð áhersla á faglegt sjálfstæði kennara, starfspróun og góðar vinnuaðstæður í skólum. Finnski grunnskólinn starfar í anda skóla án aðgreiningar en aðstoðarkennarar og sérkennarar vinna með umsjónarkennara við að koma til móts við nemendur sem purfa sérhæfðan stuðning. Um 30\% nemenda fá stuðning af einhverju tagi (skv. tölum árið 2012 og 2013) og lögð er áhersla á snemmtæka íhlutun og forvarnir (Sahlberg, 2017).

Fyrir tæpum 20 árum urđu áhyggjur af kennaraskorti tilefni pess að sett var á fót nefnd á vegum menntamálaráðherra til að meta pörf á nýliðun í hópi grunnskólakennara (Hrólfur Kjartansson o.fl., 1999). Í nefndarálitinu kemur fram að 70\% útskrifaðra grunnskólakennara skili sér í kennslu en að talsvert brottfall sé, og af kennurum undir prítugu hætti um 21\% eftir ár í starfi. Nefndin taldi að aðgerða væri pörf til að fjölga réttindakennurum en aðsókn var pó ekki vandamál á pessum árum par sem aðeins hluti umsækjenda fékk inngöngu. Lagt var til að gera háskólunum kleift að taka við fleirum og í kjölfarið var samið við Kennaraháskólann og Háskólann á Akureyri um verulega fjölgun kennaranema.

Í úttekt á mönnun grunnskólakennarastéttarinnar fjórum árum seinna var pví spáð að 20082009 yrði „kennaraskortur óverulegur eða jafnvel úr sögunni að óbreyttum forsendum matsins“ (Ríkisendurskoðun, 2003, bls. 5). Aðgerðir til að fjölga kennurum höfðu skilað árangri og hlutfall leiðbeinenda í kennslu lækkaði, sérstaklega á landsbyggðinni, par sem pað hafði verið hátt (sjá nánar mynd 1). Eftir efnahagshrunið árið 2008 hélt leiðbeinendum áfram að fækka. Á árunum 2011 til 2014 voru leiðbeinendur á öllu landinu að meðaltali 4\% peirra sem sinntu kennslu í grunnskólum en hlutfall peirra var 9\% árið 2017, hæst á Vestfjörðum, par sem pað var 27\%, og á Austurlandi og Suðurnesjum, par sem pað var 18\%.

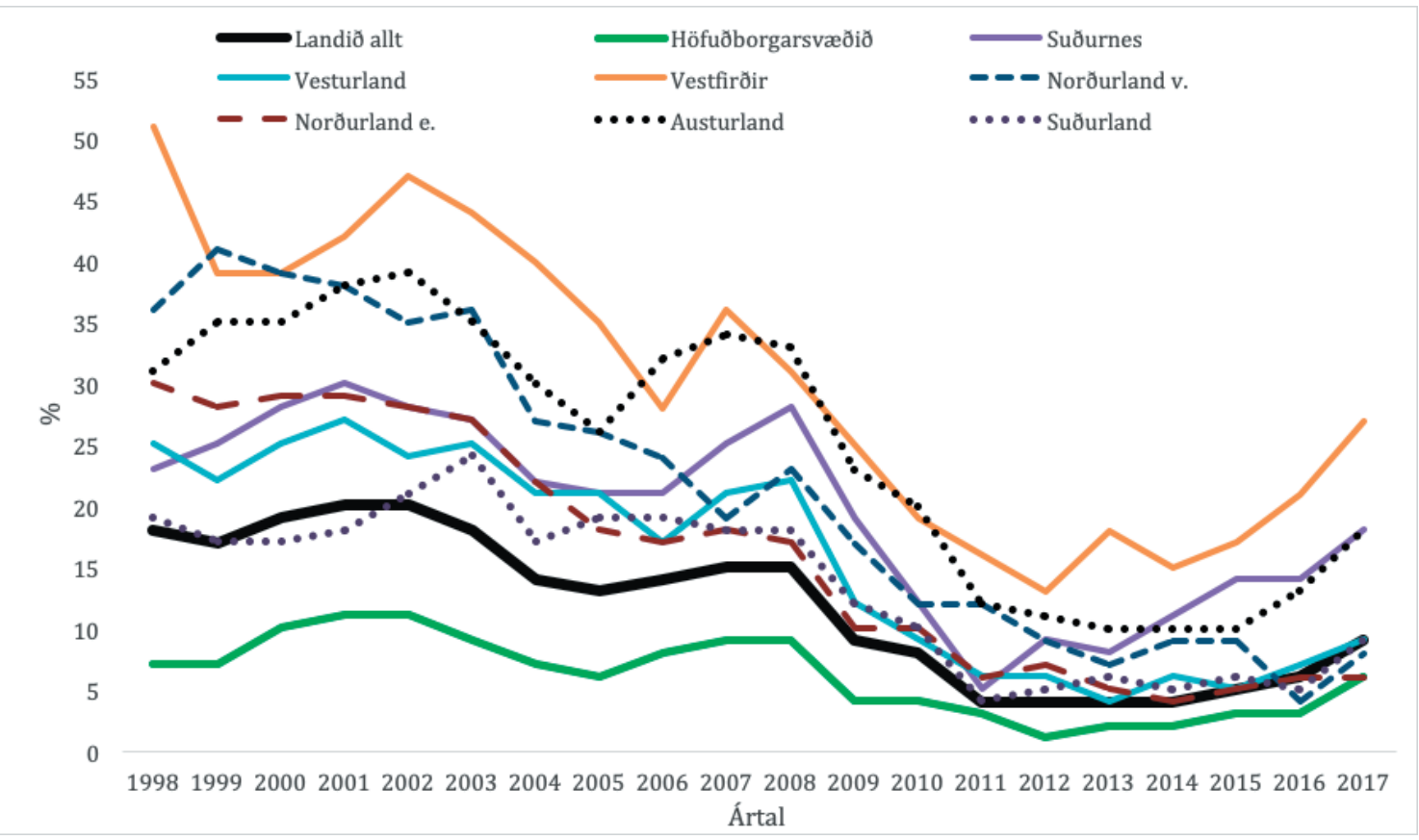

Mynd 1. Hlutfall leiðbeinenda við kennslu í grunnskólum árin 1998 til 2017 (Hagstofa Íslands, 2018b). 
Meðalaldur grunnskólakennara hækkaði á pessu tímabili; hann var 43,7 ár árið 1998 en 47,7 ár árið 2017 (Hagstofa Íslands, 2018c). Í rannsókn árið 2017 er pví spáð að á næstu 15-20 árum muni grunnskólakennurum fækka, bæði vegna hækkandi aldurs og lítillar nýliðunar. Prefalda purfi fjölda útskrifaðra kennara á næstu níu árum miðað við pað sem hann var 2015 til að fjöldi réttindakennara verði sá sami árið 2031 og hann var 2015. En sé gert ráð fyrir fjölgun grunnskólanemenda, sem er líklegt, pá purfi peim að fjölga enn meira (Helgi Eiríkur Eyjólfsson, 2017; Helgi Eiríkur Eyjólfsson og Stefán Hrafn Jónsson, 2017).

Vísbendingar eru um að kennaranemar sem ljúka fimm ára kennaranámi skili sér betur til starfa í skólum en peir sem luku priggja ára námi. Í könnun meðal tveggja fyrstu árganga grunnskólakennara brautskráđra úr fimm ára námi árin 2014 til 2015 kom í ljós að á fyrsta ári eftir útskrift voru 77\% að kenna í grunnskólum en 10\% í leikskólum (Sigríður Sigurjónsdóttir og Anna Kristín Sigurðardóttir, 2017). Í könnun haustið 2016 kom að ljós að af peim 127 sem pá höfðu lokið fimm ára grunnskólakennaranámi á Menntavísindasviði voru 80\% í Félagi grunnskólakennara, 12\% í Félagi leikskólakennara, innan við 1\% í Félagi framhaldsskólakennara og 7\% voru ekki í Kennarasambandi Íslands (Duríður Jóhannsdóttir, 2016). Í niðurstöðum Sigríðar og Önnu Kristínar (2017) kom fram að 80\% höfðu hug á að gera kennarastarfið að framtíðarstarfi og 59\% sögðu starfið hafa gengið vel. Af grunnskólakennurum höfðu 18\% kennt við sama skóla áður en peir luku námi og $22 \%$ höfðu verið í vettvangsnámi í skólanum sem peir starfa við. En jafnvel pótt nemar sem lokið hafa fimm ára grunnskólakennaranámi skili sér frekar til starfa vegur pað engan veginn upp á móti peirri fækkun sem orðið hefur á síðustu árum í náminu.

\section{Aðsókn í kennaranám, brottfall og hæg námsframvinda}

Lög um fimm ára kennaranám tóku gildi árið 2009 og síðustu kennararnir sem luku priggja ára kennaranámi með réttindum voru brautskráđir árið 2011. Á mynd 2 sést fjöldi grunnskólakennaranema á landinu öllu sem brautskráđust með B.Ed-gráðu árin 1995-2016 samkvæmt tölum frá Hagstofu Íslands. Par sést að fleiri ljúka slíku námi á árabilinu 2004 til 2011, í kjölfar átaks til að fjölga réttindakennurum, en tíu árin par á undan en síðan dregst fjöldinn saman aftur pegar kennaranámið hefur verið lengt. Deir fyrstu sem luku fimm ára meistaranámi brautskrádust árið $2014^{2}$ og pó að fáir hafi lokið námi fyrstu árin hefur brautskráningum farið fjölgandi, pannig að pær voru 79 skólaárið 2015-2016. Tölur frá Hagstofu Íslands ná ekki lengra aftur, en í nefndaráliti frá 1999 (Hrólfur Kjartansson o.fl., 1999) kemur fram að 1992-1995 útskrifaðist að meðaltali 121 grunnskólakennari á ári úr B.Ed-námi við Kennaraháskólann.

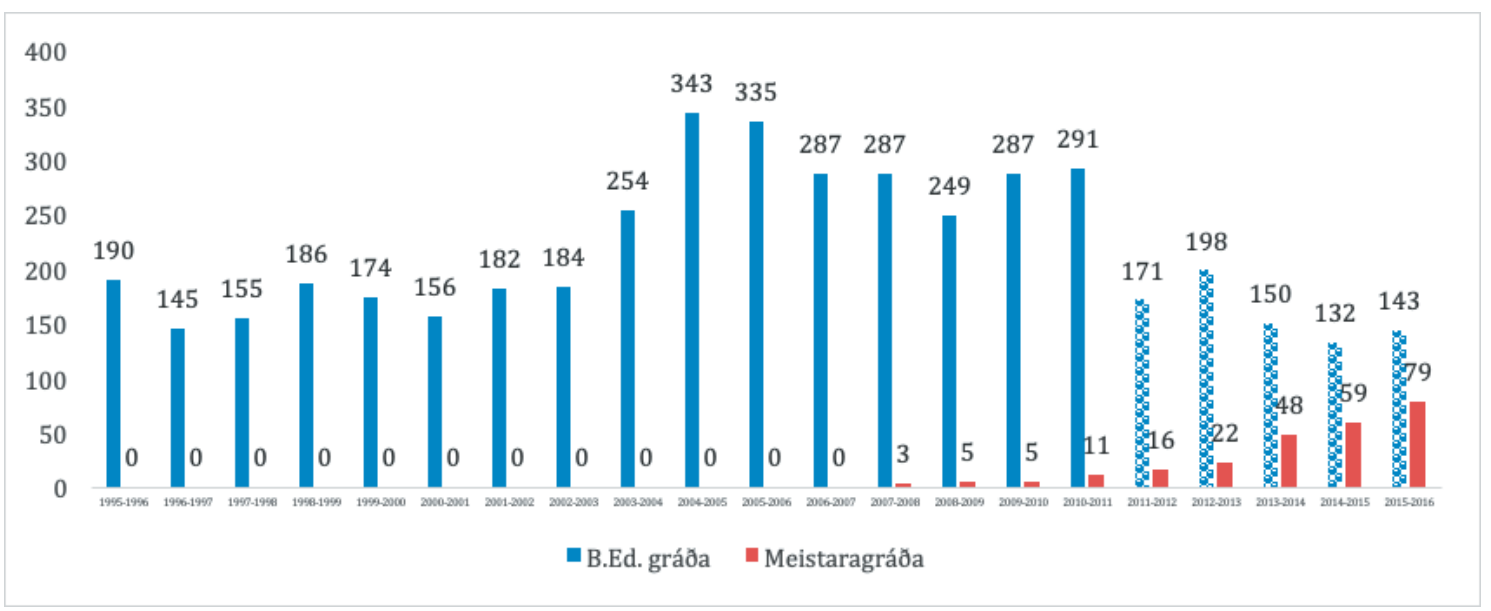

Mynd 2. Fjöldi brautskráðra grunnskólakennaranema með B.Ed- og M.Ed-gráðu í grunnskólakennarafræðum árin 1995-2016 (Hagstofa Íslands, 2018d).

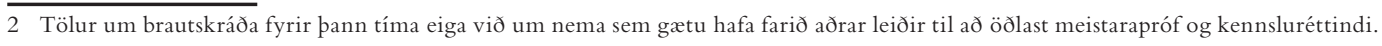


Haustið 2008 innrituðust síðustu kennaranemarnir sem gátu lokið réttindanámi á premur árum og pá voru 278 nýnemar skráđir í grunnskólakennaranám við Menntavísindasvið Háskóla Íslands. Ś̉ðan dregur smám saman úr aðsókn; haustið 2010 voru nýnemar 189, 114 árið 2012 og 79 árið 2016 (Háskóli Íslands, e.d.). Á mynd 3 má sjá fjölda nýnema og brautskráðra úr grunnskólakennaranámi við Menntavísindasvið árin 2011-2017. Árið 2012 innrituðust fyrstu kennaranemarnir í meistaranám í grunnskólakennarafræðum að loknu B.Ed prófi. Dað ár luku 111 bakkalárprófi en einungis 51, eða 46\%, hóf meistaranám sama ár. Alls hafa 536 lokið B.Edprófi frá Menntavísindasviði á tímabilinu 2012-2017 en á sama tíma hafa 149 lokið M.Ed.-prófi að loknu B.Ed-prófi og 34 eftir BA/BS-próf. Frá lengingu kennaranámsins hafa pví 183 lokið grunnskólakennaraprófi frá Menntavísindasviði.

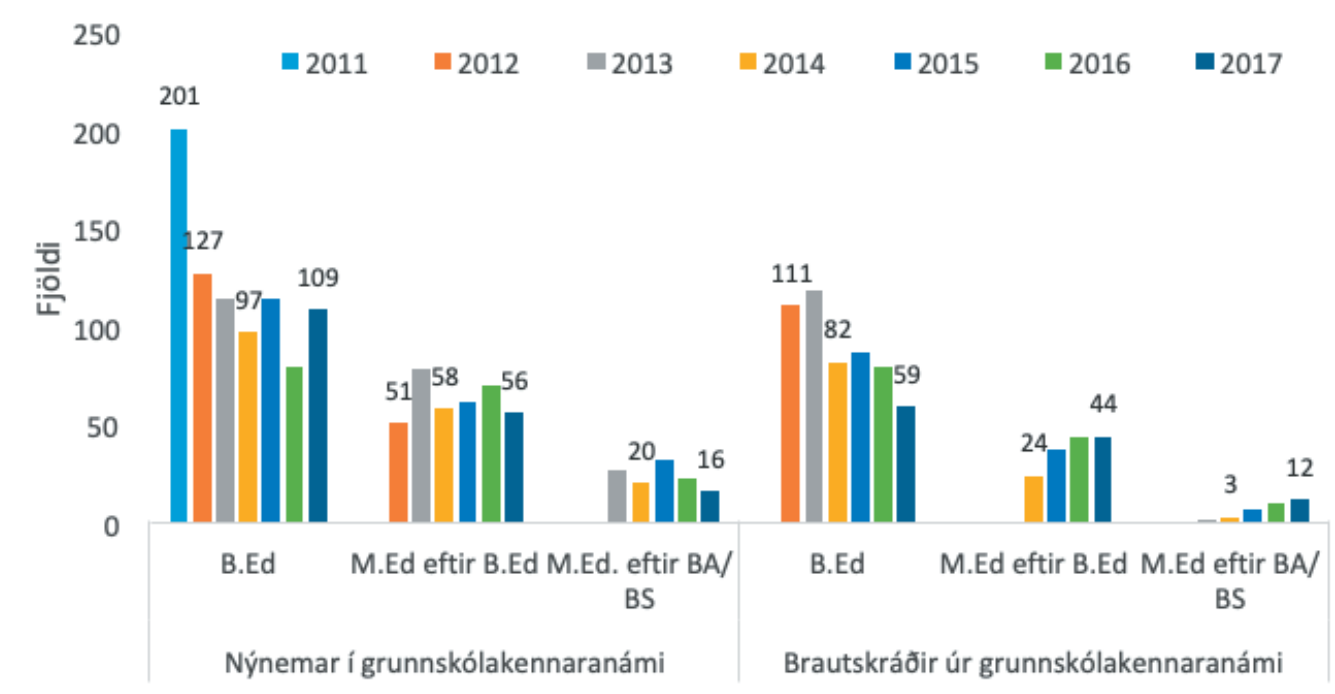

Mynd 3. Nýnemar og brautskráđir með B.Ed- og M.Ed-gráðu við Menntavísindasvið eftir árum.

Minnkandi aðsókn í grunnskólakennaranám, brottfall og hæg námsframvinda er áhyggjuefni víðar en á Íslandi. Баð sama á við um öll Norðurlöndin nema Finnland sem sker sig úr að pessu leyti eins og í árangri finnskra nemenda á albjóðlegum prófum og könnunum (Rasmussen og Dorf, 2010). Lenging námsins er pví líklega ekki eina skýringin á minnkandi ađsókn. Hún var hafin fyrr, en á árunum 2004-2007 dróst ađsókn í kennaranám á Íslandi saman um 40\%, eða úr 443 umsækjendum árið 2004 niður í 266 árið 2007 (Petersen, 2010). Á sama tíma dróst aðsókn í Danmörku saman um 37\% og 22\% í Noregi og Svípjóð (Rasmussen og Dorf, 2010). Staðan var önnur í Finnlandi, en á árunum 2001-2014 var aðeins hægt að taka við tæpum 10\% af peim sem sóttu um námið (Sahlberg, 2017). Drátt fyrir petta eru of fáir umsækjendur um kennslu í náttúrufræðigreinum í Finnlandi (Juuti, Christophersen, Elstad, Solhaug og Turmo, 2018) og of fáir karlmenn sækjast eftir kennaranámi, en 80\% grunnskólakennara par eru konur (Sahlberg, 2017). Mikla aðsókn í kennaranám í Finnlandi er ekki hægt að skýra með betri launum en í öðrum löndum, en eftir 15 ára starf eru pau nálægt meðallaunum í OECD-ríkjunum (OECD, 2014; Sahlberg, 2017). En kennarastarfið nýtur virðingar og vegna mikillar aðsóknar eru bæði skrifleg inntökupróf og viðtöl notuð til að velja bestu kennaraefnin. Allir grunnskólakennarar purfa að taka fimm ára meistaranám, annars vegar er nám fyrir bekkjarkennara í 1.-6. bekk og hins vegar er nám fyrir kennara í námsgreinum unglingastigs og framhaldsskóla. Vettvangsnám fer oftast fram í sérstökum æfingaskólum sem hafa pjálfaða leiðsagnarkennara (Sahlberg, 2017).

Til viðbótar við minnkandi aðsókn er mikið brottfall úr kennaranámi áhyggjuefni. Brottfall úr kennaranámi í Danmörku, Noregi og Svípjóð var um 35\% að meðaltali í öllum löndunum á árunum fyrir 2008 en 20\% á Íslandi (Rasmussen og Dorf, 2010). Á árunum 2013-2015 hafði brottfall úr kennaranámi á Íslandi hins vegar aukist; að meðaltali héldu 55\% nema í bakkalárnámi áfram á öðru ári við Menntavísindasvið en 65\% við Háskólann á Akureyri (Ríkisendurskoðun, 2017) en parna er brottfall skilgreint sem endurkomuhlutfall nýnema. 


\section{Fjarnám og óhefðbundnar leiðir - einkenni fjarnema og staðnema}

Vandamálið við að mennta nægilega marga kennara hefur kallað á tilraunir með próun óhefðbundinna leiða í kennaramenntun (Humprey, Wechsler og Hough, 2008; Lára Stefánsdóttir og Sigurjón Mýrdal, 1993; Duríður Jóna Jóhannsdóttir, 2010; Duríður Jóhannsdóttir, 2013). Í skýrslu frá UNESCO (Schwille og Dembélé, 2007) er fjallað um umbætur í menntun kennara og hvað purfi að gera til að laða fleiri í kennaranám. Víða er boðið upp á nám til kennsluréttinda par sem leiðbeinendum sem starfa í skólum er boðið upp á fræðilegt nám í fjarnámi/netnámi eða utan hefðbundins skólatíma, og pannig var fjarnámið við Kennaraháskólann skipulagt í upphafi (Lára Stefánsdóttir og Sigurjón Mýrdal, 1993). Með pví móti hefur verið hægt að ná til hópa sem annars hefðu ekki íhugað kennaranám, t.d. vegna búsetu og/eða fjölskylduaðstæðna (Humprey o.fl., 2008; Robinson og Latchem, 2003).

Degar fjarnám hófst í Kennaraháskólanum árið 1993 var gert ráð fyrir að flestir kennaranemarnir væru í starfi sem leiðbeinendur í grunnskólum eða hefðu reynslu af kennslu og mælst var til pess að peir væru ekki í meira en hálfu starfi með námi (Kennslan gekk vonum framar, 1996). Námið var skipulagt sem fjögurra ára nám í stað priggja og sérstakur fjarnámsstjóri við Kennaraháskólann hafði umsjón með pví. Fjarnemar mættu í staðbundnar lotur, venjulega utan skólatíma, í lok jólafrís og í upphafi sumarfrís, og samskipti fóru fram á netinu sem skólar landsins höfđu nýlega tengst (Lára Stefánsdóttir og Sigurjón Mýrdal, 1993; Jón Jónasson, 2001; Duríður Jóna Jóhannsdóttir, 2010). Mikil aðsókn var að fjarnáminu og í upphafi takmarkaðist sá fjöldi sem hægt var að taka inn af fjárveitingum pannig að af 200 umsækjendum voru aðeins 80 eða 40\% teknir inn í fyrsta hópinn árið 1993 (Kennslan gekk vonum framar, 1996). Um aldamótin voru um 43\% umsækjenda tekin inn í grunnskólakennaranám í fjarnámi en 69\% umsækjenda í staðnám (Auður Kristinsdóttir, Ásrún Matthíasdóttir og M. Allyson Macdonald, 2001). Auknar fjárveitingar til Kennaraháskólans og Háskólans á Akureyri leiddu til pess að fleiri umsækjendur voru teknir inn og síðasta árið sem Kennaraháskólinn starfaði voru 85\% umsækjenda tekin inn í grunnskólakennaranámið (Kennaraháskólinn, 2008).

Lítið brottfall úr fjarnámi fyrstu árin vakti athygli, en á árunum 1993 til 2001 var brottfall ekki nema $11 \%$ ef frá er talinn fyrsti hópurinn par sem brottfall var 20\% (Auður Kristinsdóttir o.fl., 2001). Eftir að aðgengi í fjarnám var opnað fyrir alla sem uppfylltu skilyrði um inngöngu í háskóla eftir aldamótin fór brottfall að aukast og í hópnum sem hóf nám 2004 var brottfall 33\% en ekki nema 14\% hjá staðnemum (Sólveig Jakobsdóttir, Elsa Sigríður Jónsdóttir, Hanna Lilja Valsdóttir, Ingibjörg B. Frímannsdóttir og Puríður Jóhannsdóttir, 2008).

Rétt eftir aldamót bjuggu 87\% fjarnema á landsbyggðinni og 42\% staðnema (Auður Kristinsdóttir o.fl., 2001). Smám saman dregur úr hlutfalli landsbyggðarfólks í hópi fjarnema. Árið 2004 bjó 31\% fjarnema í hálftíma akstursfjarlægð frá skólanum en haustið 2007 voru 46\% fjarnema í peirri stöðu. Árið 2004 var 41\% fjarnema yfir tvær klst. á leið í skólann en árið 2007 bjó priðjungur í meira en tveggja klst. akstursfjarlægð eða í útlöndum (Amalía Björnsdóttir, 2009; Sólveig Jakobsdóttir o.fl., 2008).

Fjarnám opnaði möguleika á að taka nám með vinnu. Um aldamótin voru 92\% fjarnema í vinnu og par af voru $72 \%$ að kenna (miðað er við bæði leik- og grunnskólakennaranema). Um helmingur var í 80\% starfi eða meira (Auður Kristinsdóttir o.fl., 2001). Í könnun árið 2004 sögðust 78\% fjarnema í grunnskólakennaranámi vinna með námi en 51\% staðnema. Helmingur fjarnema en $4 \%$ staðnema unnu pá meira en 30 klst. á viku. Af fjarnemum unnu 44\% sem leiðbeinendur í grunnskóla en 1\% staðnema (Amalía Björnsdóttir, 2009). Skólaárið 2007-2008 voru 73\% fjarnema í grunnskólakennaranámi í launaðri vinnu og 53\% unnu meira en sem nam 75\% starfshlutfalli (Sólveig Jakobsdóttir o.fl., 2008). Skólaárið 2010-2011 voru 60\% bæði fjarog staðnema í vinnu með námi og voru 43\% fjarnema í kennslu- eða uppeldisstörfum en um fjórðungur staðnema. Um 32\% fjarnema voru í meira en 75\% starfi en enginn staðnemi (Duríður Jóhannsdóttir og Sólveig Jakobsdóttir, 2011). 
Skólaárið 2010-2011 var skipulagi breytt pannig að fjarnemar og staðnemar voru saman í námskeiðum en ekki í aðskildum hópum eins og áður og eftir pað eru peir ekki skráðir eftir námsformi (Duríður Jóhannsdóttir og Sólveig Jakobsdóttir, 2011). Dví er ekki hægt að fylgjast með brottfalli eða námsframvindu eftir námsformi. Samkennsla stað- og fjarnema var að hluta til tekin upp vegna kröfu um sparnað í kjölfar efnahagshrunsins en einnig sem tækifæri til að próa sveigjanlegri kennsluhætti. Faglegur ávinningur var talinn geta verið að pví að kenna báðum hópum saman og mismunandi bakgrunnur og reynsla geta víkkað sjóndeildarhring og styrkt námið. Í samkennsluforminu er almennt gert ráð fyrir að fjarnemar og staðnemar komi saman í nokkurra daga staðlotu tvisvar á misseri. Staðnemar fá síðan reglubundna vikulega kennslu en fjarnemar stunda námið á netinu. Námsefni er aðgengilegt fyrir alla á námskeiðsvef og fjarnemar geta par átt samskipti við kennara og samnema.

Eftir að nýju lögin komu til framkvæmda árið 2009 var skipulag náms grunnskólakennara sett upp sem fimm ára nám sem unnt væri að taka annaðhvort í stað- eða fjarnámi. Nemendur velja námsform eftir hentugleikum í hverju námskeiði og stýra sjálfir námshraðanum.

\section{Rannsóknir á óhefðbundnum leiðum í kennaranámi}

Óhefðbundnar námsleiðir í kennaranámi gegna mikilvægu hlutverki víða um heim en rannsóknir hefur skort á einkennum peirra og ávinningi af peim. Humprey o.fl. (2008) vildu bæta úr pessu og gerðu tilviksrannsóknir á sjö völdum óhefðbundnum námsleiðum í Bandaríkjunum. Í flestum tilvikum voru kennaranemar starfandi við kennslu með náminu (e. school-based teacher education). Næstum helmingur peirra hafði reynslu af kennslu eða skólastarfi áður en peir hófu kennaranámið. Athugað var hvort fyrri reynsla af kennslu hefði áhrif á trú kennara á eigin getu (e. teacher efficacy). Deir sem höfðu reynslu voru marktækt líklegri til að hafa trú á eigin getu en peir sem enga reynslu höfðu áđur en peir byrjuðu í náminu. Rannsakað var hvaða pættir einkenndu pær námsleiðir sem skiluðu góðum árangri, p.e. að kennarar væru líklegir til að vilja verða kennarar og að peir gætu orðið góðir kennarar. Mikilvægasti pátturinn í farsælu kennaranámi reyndist vera skólinn par sem kennaranemar voru við kennslu jafnhliða náminu. Par sem skólamenning einkenndist af góðum tengslum vinnufélaga, styrkri stjórnun og nægum björgum voru kennaranemar miklu líklegri til að segjast vilja starfa við kennslu. Deir sem kenndu í skólum par sem aðstæður voru krefjandi og erfiðar voru aftur á móti miklu óákveðnari varðandi framtíð sína í kennslu. Í öđru lagi skipti máli að vel menntað fólk væri fengið til að styrkja pekkingu kennaranema í námsgreinum og að leitast væri við að tengja hana við fyrri reynslu kennaranemans úr kennslu. Í priðja lagi var mikilvægt að pess væri gæett að verkefnin sem lögð voru fyrir í háskólanáminu væru í samræmi við bakgrunn kennaranemans og aðstæður í skólanum par sem hann kenndi og pau væru lögð fyrir á viðeigandi tíma. Pá var einnig mikilvægt að pjálfaðir leiðsagnarkennarar væru til staðar í skólunum og að peir hefðu tíma og aðstæður til að skipuleggja kennslu með kennaranemunum, ræða inntak kennslustunda, sýna peim dæmi um góða kennslu, fylgjast með peim kenna og veita endurgjöf. Niðurstöðurnar benda til pess að óhefðbundnar námsleiðir geti menntað kennara sem hafa pá pekkingu sem parf til að stunda kennslu, hafa trú á eigin getu og endast í starfi. Vakin var sérstök athygli á pví hvað skólinn par sem kennaranemar starfa skiptir miklu máli og að vanda purfi val á peim (Humprey o.fl., 2008).

Sambærileg niðurstaða kom fram í rannsókn fyrri höfundar, Duríðar Jónu Jóhannsdóttur (2010), sem snerist um pað hvernig kennaranemar, sem voru leiðbeinendur í grunnskólum, lærðu að verða kennarar með pví að taka kennaranám í fjarnámi. Í ljós kom að gæði kennaranámsins tengdust skólunum par sem nemarnir kenndu og að fræðilega námið í háskólanum gagnaðist peim með mismunandi hætti eftir aðstæðum í skólunum (Duríður Jóhannsdóttir, 2012; Duríður Jóhannsdóttir og Roth, 2014). Kennaranemarnir höfðu ekki leiðsagnarkennara í sínum heimaskóla en stuðningur skólastjórnenda og samvinnuandi í kennarahópnum skipti máli. Rannsókn Duríðar leiddi einnig í ljós hve mikilvægt pað var að háskólakennarar tækju mið af sérstöðu kennaranema sem voru við kennslu og byggðu á reynslu peirra við fyrirlögn verkefna (Duríður Jóhannsdóttir, 2015). Duríður bendir á mikilvægi pess að kennaramenntunin taki mið af aðstæðum peirra kennaranema sem eru við kennslu og að leitast sé við að tengja saman reynslu og fræðilegt nám. Hún leggur pví til að samstarf skóla og háskóla sem mennta kennara sé eflt. 
Margt bendir til pess að staðnemar og fjarnemar séu ólíkir hópar og að pegar hæg framvinda í námi sé vandamál purfi að huga að pví hvort munur sé á fjarnemum og staðnemum og peim sem taka námskeið bæði í stað- og fjarnámi og hvort bregðast purfi ólíkt við eftir pörfum pessara hópa. Nýleg bandarísk rannsókn (Bailey, Henry, Laverdiere og Pugliese, 2018) sýndi að námsframvinda pess nemendahóps sem tók námskeið bæði í staðnámi og fjarnámi - ýmist alveg í fjarnámi eða með staðlotum - var töluvert hraðari og minna brottfall en í hinum tveim hópunum. Á grundvelli pess er mælt með að skólar bjóði upp á sveigjanleika pannig að hægt sé að taka námskeið ýmist í fjarnámi eđa staðnámi. Pá sé mikilvægt að leitast við að skilja sérstakar aðstæður ólíkra hópa og bjóða peim viðeigandi sveigjanleika til að gera peim kleift að stunda nám. Баð er pví víða um heim verið að huga að mikilvægi pess að greina ólíka hópa stúdenta í háskólanámi, sem er forsenda pess að geta uppfyllt ólíkar parfir peirra í skipulagi náms og kennslu.

Í rannsókn okkar voru rannsóknarspurningarnar:

Hver er munurinn á bakgrunni kennaranema í stað- og fjarnámi?

Hvaða pættir tengjast pví hvort kennaranemar telja kennarastarfið eftirsóknarvert

(aðdráttarafl starfsins)?

\section{Аðferð}

\section{Dátttakendur}

Pátttakendur voru nemendur $(N=208)$ ífimm ára grunnskólakennaranámi við Menntavísindasvið Háskóla Íslands. Frekari upplýsingar um pá má sjá í töflu 1 en mikill meirihluti pátttakenda var konur, eða tæp $87 \%$ peirra sem svöruðu peirri spurningu. Dátttakendur voru á öllum fimm námsárum kennaranáms en hlutfallslega fleiri pátttakendur voru á fyrstu premur námsárunum og er pað í samræmi við fjölmennari árganga nema á B.Ed-stigi en á M.Ed-stigi. Af peim sem svöruðu spurningu um námsform sögðust 47\% pátttakenda vera í staðnámi, um 34\% í fjarnámi og fimmtungur var bæði í stað- og fjarnámi, pað er tóku námskeið ýmist sem fjar- eða staðnemar.

Tafla 1. Pátttakendur í rannsókninni.

\begin{tabular}{lccc}
\hline & Fjöldi & $\begin{array}{c}\text { Hlutfall (\%) } \\
\text { af öllum } \\
\text { pátttakendum }\end{array}$ & $\begin{array}{c}\text { Hlutfall (\%) } \\
\text { af peim sem svara } \\
\text { viðkomandi spurningu }\end{array}$ \\
\hline Kyn & & & \\
\hline Kona & 168 & 80,8 & 87,0 \\
Karl & 25 & 12,0 & 13,0 \\
Svara ekki & 15 & 7,2 & \\
Námsár & & & 24,6 \\
\hline 1. ár & 51 & 24,5 & 27,5 \\
2. ár & 57 & 27,4 & 14,0 \\
3. ár & 43 & 20,7 & 13,0 \\
4. ár & 29 & 13,9 & \\
5. ár & 27 & 13,0 & 33,7 \\
Svara ekki & 1 & 0,5 & 46,8 \\
Námsform & & & 19,5 \\
\hline Fjarnám & 64 & 30,8 & \\
Staðnám & 89 & 42,8 & \\
Bæði stað- og fjarnám & 37 & 17,8 & \\
Svara ekki & 18 & 8,7 & \\
\hline
\end{tabular}


Tafla 2. Mældir pættir, fylgibreyta og frumbreytur.

\begin{tabular}{|c|c|c|}
\hline Páttur & Alfa & Staðhæfingar \\
\hline $\begin{array}{l}\text { Aðdráttarafl } \\
\text { kennarastarfsins }\end{array}$ & 0,83 & $\begin{array}{l}\text { Ég hlakka til að vinna sem kennari. } \\
\text { Mér finnst góð tilhugsun að verða kennari. } \\
\text { Mér finnst ég tengd/ur kennarastarfinu. }\end{array}$ \\
\hline $\begin{array}{l}\text { Uppeldis- og } \\
\text { kennslufræði }\end{array}$ & 0,93 & $\begin{array}{l}\text { Í náminu i uppeldis- og kennslufræði } \\
\text {...fæ ég hagnýt dæmi úr raunverulegri kennslu. } \\
\text {...læri ég um fræðilegt efni sem er gagnlegt í kennslu. } \\
\text {...eru gefin viðeigandi dæmi úr skólastarfi. } \\
\text {...eru tengsl milli uppeldis- og kennslufræði og kennarastarfsins } \\
\text { skýr. }\end{array}$ \\
\hline $\begin{array}{l}\text { Kennslufræði } \\
\text { greina }\end{array}$ & 0,94 & $\begin{array}{l}\text { Í kennslufræði faggreina } \\
\text {...fæ ég hagnýt dæmi úr raunverulegum kennslustundum. } \\
\text {...læri ég um fræðilegt efni sem er gagnlegt í kennslu. } \\
\text {...eru gefin viðeigandi dæmi úr skólastarfi. } \\
\text {...eru tengsl milli kennslufræði faggreina og kennarastarfsins } \\
\text { skýr. }\end{array}$ \\
\hline $\begin{array}{l}\text { Samræður við } \\
\text { æfingakennara }\end{array}$ & 0,81 & $\begin{array}{l}\text { Í vettvangsnáminu } \\
\text {...benda leiðsagnarkennarar á raunveruleg dæmi um pað sem við } \\
\text { höfum lært í fræðilega hluta námsins. } \\
\text {...kynnist ég hvaða máli námsgreinin sem ég kenni skiptir í } \\
\text { skólanum. } \\
\text {...ræði ég við leiðsagnarkennara um hvernig nýta má } \\
\text { námsgreinina til að próa kennsluhætti. } \\
\text {...ræði ég við leiðsagnarkennara um reynslu mína á vettvangi í } \\
\text { ljósi pess sem við höfum verið að læra. }\end{array}$ \\
\hline $\begin{array}{l}\text { Hæfni } \\
\text { æingakennara við } \\
\text { að tengja saman } \\
\text { fræði og starf }\end{array}$ & 0,90 & $\begin{array}{l}\text { Leiðsagnarkennarinn (æfingakennarinn) } \\
\text {...pekkir vel hvað ég hef lært í uppeldis- og kennslufræði og } \\
\text { kennslufræði faggreina. } \\
\text {...hjálpar mér að tengja saman kenningar og starf. } \\
\text {...útskýrir pað sem er óljóst í námsefninu. } \\
\text {...skýrir tengslin á milli kenninga í uppeldis- og kennslufræði } \\
\text { og pess sem ég upplifi í skólunum. }\end{array}$ \\
\hline
\end{tabular}

Samræður við leiðsagnarkennara í heimaskólanum hjálpuðu mér ... að skilja hvað ég parf að gera til að undirbúa mig sem kennari.

Endurgjöf og leiðsögn frá æfingakennurum
... аð forgangsraða daglegum verkefnum mínum sem kennaranema.

0,89 Leiðsagnarkennarar í heimaskóla gáfu mér skýra endurgjöf um hvernig ég stend mig í kennslunni.

Endurgjöf frá leiðsagnarkennurum var í góðu samræmi við hvernig mér gekk.

Endurgjöf frá leiðsagnarkennurum hjálpaði mér við að skilja til hvers var ætlast af mér sem kennaranema 


\section{Framkvæmd}

Gögnum var safnað með rafrænni könnun og fór gagnasöfnun fram í mars og apríl árið 2017. Krækja í könnunina var send nemendum í tölvupósti en auk pess var könnunin kynnt í kennslustundum og nemendur hvattir til pátttöku. Nemendur fengu einnig senda hvatningu í tölvupósti, meðal annars frá kennurum í námskeiðum sem peir sóttu.

Könnunin var nafnlaus og pátttakendum var greint frá pví að peir pyrftu ekki að svara henni og að peir mættu sleppa einstökum spurningum.

\section{Mælitækið og úrvinnsla}

Spurningalistinn sem var notaður var pýddur á íslensku úr norsku af rannsakendum með aðstoð íslenskra fræðimanna sem starfa við norska háskóla. Listinn hafði áður verið notaður til gagnaöflunar í Noregi (Christophersen, Elstad, Solhaug og Turmo, 2016) og Finnlandi (Christophersen, Elstad, Juuti, Solhaug og Turmo, 2017).

Í spurningalistanum eru spurningar á Likert-kvarða með sjö svarmöguleikum. Hver páttur sem notaður var í úrvinnslu í pessari grein var mældur með premur til fimm spurningum og var áreiðanleiki (alfa) fyrir pá í öllum tilfellum góður (alfa > 0,8), sjá töflu 2.

Pátttakendur voru einnig spurðir um bakgrunn sinn og pátttöku á vinnumarkaði með fram námi. Spurt var um menntun foreldra, hvort foreldrar væru kennarar, atvinnupátttöku, bæði við hvað var starfað og hversu marga tíma á viku að jafnaði. Að lokum var spurt hvort pátttakendur væru fjarnemar, staðnemar eða tækju námskeið bæði í fjar- og staðnámi.

Reiknuð var lýsandi tölfræði og áreiðanleiki var metinn bæði fyrir fylgibreytu og frumbreytur. Í úrvinnslu var fylgibreytunni aðdráttarafl kennarastarfsins breytt 1 tvískipta breytu, pá sem voru með 6 stig eða hærra $(N=94)$ á móti peim sem voru með lægra en 6 stig $(N=112)$. Reiknuð voru hlutfallslíkindi OR (e. odds ratio) en pví fjær 1 sem hlutfallslíkindi eru, peim mun meiri eru áhrif frumbreytunnar. Ef hlutfallslíkindi eru 1 hefur frumbreyta engin áhrif. Reiknuð voru 95\% öryggisbil (ÖB). Aðhvarfsgreining hlutfalla (e. logistic regression) var notuð til að meta forspá frumbreytna um breytileika í fylgibreytunni aðdráttarafl kennarastarfsins. Bæði voru könnuð einföld tengsl hverrar breytu við fylgibreytuna en einnig sett upp prjú líkön par sem könnuð voru áhrif nokkur breytna á fylgibreytuna. SPSS 24 var notað við gagnagreiningu.

\section{Niðurstöður}

Í töflu 3 má sjá menntun foreldra pátttakenda eftir námsformi og voru par vísbendingar um minni menntun foreldra fjarnema en foreldra staðnema og nema í stað- og fjarnámi. Kennaranemar í fjarnámi eru líklegri en staðnemar til að eiga móður með grunnskólamenntun eða sambærilegt $(O R=2,24, p=0,033)$ og ólíklegri til að eiga móður með háskólamenntun $(\mathrm{OR}=0,46, p=$ $0,026)$ en ekki var munur á nemum í staðnámi og blönduðu námi. Ekki fannst munur á líkum á að eiga föður með grunnskólamenntun eftir námsformi en nemendur í fjarnámi voru síður líklegir en staðnemar til að eiga föður með háskólapróf $(O R=0,21, p<0,001)$. Ekki fannst munur pegar bornir voru saman staðnemar og nemar í blönduðu námi.

Um fjórðungur pátttakenda átti foreldra eða foreldri sem var kennari. Tæp 15\% áttu móður sem var kennari, tæp 4\% föður og tæp 7\% sögðu báða foreldra sína vera kennara. Staðnemar voru líklegri en fjarnemar til að eiga foreldra sem voru kennarar $(O R=2,4, p=0,036)$ en ekki var munur á staðnemum og nemum í blönduðu námi. 
Tafla 3. Menntun foreldra eftir námsformi.

\begin{tabular}{|c|c|c|c|c|c|c|c|c|}
\hline & \multicolumn{2}{|c|}{ Fjarnám } & \multicolumn{2}{|c|}{ Stað̃nám } & \multicolumn{2}{|c|}{ Blandad } & \multicolumn{2}{|c|}{ Allir } \\
\hline & $\%$ & $\mathbf{N}$ & $\%$ & $\mathbf{N}$ & $\%$ & $\mathbf{N}$ & $\%$ & $\mathbf{N}$ \\
\hline \multicolumn{9}{|l|}{ Menntun mæðra } \\
\hline Háskólamenntun & 28,6 & 18 & 46,6 & 41 & 48,6 & 18 & 41,0 & 77 \\
\hline Stúdentspróf & 19,0 & 12 & 19,3 & 17 & 10,8 & 4 & 17,6 & 33 \\
\hline Iðnmenntun/ styttra starfsnám & 17,5 & 11 & 14,8 & 13 & 13,5 & 5 & 15,4 & 29 \\
\hline Grunnskóli eða sambærilegt & 34,9 & 22 & 19,3 & 17 & 27,0 & 10 & 26,1 & 49 \\
\hline Samtals & 100 & 63 & 100 & 88 & 100 & 37 & 100 & 188 \\
\hline \multicolumn{9}{|l|}{ Menntun feðra } \\
\hline Háskólamenntun & 12,5 & 8 & 40,9 & 36 & 35,1 & 13 & 30,2 & 57 \\
\hline Stúdentspróf & 9,4 & 6 & 3,4 & 3 & 2,7 & 1 & 5,3 & 10 \\
\hline Iðnmenntun/styttra starfsnám & 51,6 & 33 & 37,5 & 33 & 40,5 & 15 & 42,9 & 81 \\
\hline Grunnskóli eða sambærilegt & 26,6 & 17 & 18,2 & 16 & 21,6 & 8 & 21,7 & 41 \\
\hline Samtals & 100 & 64 & 100 & 88 & 100 & 37 & 100 & 189 \\
\hline \multicolumn{9}{|l|}{ Foreldrar kennaramenntaðir } \\
\hline Annað eða bæði & 15,6 & 10 & 30,7 & 27 & 29,7 & 11 & 25,4 & 48 \\
\hline Hvorugt & 84,4 & 54 & 69,3 & 61 & 70,3 & 26 & 74,6 & 141 \\
\hline Samtals & 100 & 64 & 100 & 88 & 100 & 37 & 100 & 189 \\
\hline
\end{tabular}

Kannað var hvort pátttakendur væru í launaðri vinnu samhliða námi, við hvað peir störfuðu og hversu marga tíma peir ynnu að jafnaði á viku (sjá nánar töflu 4). Sjö af hverjum tíu pátttakendum voru í launuðu starfi og er pað óháð námsfyrirkomulagi. Af fjarnemum unnu 42\% 31 klst. á viku eða meira en 5\% staðnema, og 14\% nema í blönduðu námsformi unnu 31 klst. á viku eða meira.

Tafla 4. Vinna pátttakenda með námi, vinnutími og tegund starfs

\begin{tabular}{|c|c|c|c|c|c|c|c|c|}
\hline & \multicolumn{2}{|c|}{ Fjarnám } & \multicolumn{2}{|c|}{ Staðnám } & \multicolumn{2}{|c|}{ Blandað } & \multicolumn{2}{|c|}{ Allir } \\
\hline & $\%$ & $\mathbf{N}$ & $\%$ & $\mathbf{N}$ & $\%$ & $\mathbf{N}$ & $\%$ & $\mathbf{N}$ \\
\hline Launað starf & 71,9 & 46 & 73,0 & 65 & 70,3 & 26 & 72,1 & 137 \\
\hline \multicolumn{9}{|l|}{ Vinnutími í launuðu starfi } \\
\hline Ekki að vinna & 28,1 & 18 & 27,0 & 24 & 29,7 & 11 & 27,9 & 53 \\
\hline 10 stundir eða minna & 1,6 & 1 & 21,3 & 19 & 8,3 & 3 & 12,2 & 23 \\
\hline $11-20$ stundir & 9,4 & 6 & 34,8 & 31 & 27,8 & 10 & 24,9 & 47 \\
\hline 21-30 stundir & 18,8 & 12 & 12,4 & 11 & 19,4 & 7 & 15,9 & 30 \\
\hline $31-40$ stundir & 32,8 & 21 & 4,5 & 4 & 8,3 & 3 & 14,8 & 28 \\
\hline Meira en 40 stundir & 9,4 & 6 & 0 & 0 & 5,6 & 2 & 4,2 & 8 \\
\hline \multicolumn{9}{|l|}{ Starfssvið } \\
\hline Leiðbeinandi í grunnskóla & 20,3 & 13 & 2,2 & 2 & 8,1 & 3 & 9,5 & 18 \\
\hline Í starfi tengdu náminu1 & 31,3 & 20 & 42,7 & 38 & 37,8 & 14 & 37,9 & 72 \\
\hline Starfið ótengt námi/ vinn ekki & 48,4 & 31 & 55,1 & 49 & 54,1 & 20 & 52,6 & 100 \\
\hline
\end{tabular}


Að meðaltali voru pátttakendur með 5,5 stig á kvarða sem mældi aðdráttarafl kennarastarfsins, eins og áður sagði, og par sem meðaltal á kvarðanum var hátt og dreifing mjög skökk var ákveðið að skipta hópnum í tvennt; pá sem væru háir á kvarðanum, með sex eða yfir, og pá sem væru lægri. Alls voru 94 (45,6\%) pátttakendur háir á kvarðanum og $112(54,4 \%)$ í lægri flokknum. Í framhaldinu var skoðað hvort pættir í bakgrunni hefðu áhrif á pað hvort nemar væru háir eða lágir og reyndust pau tengsl ekki marktæk (sjá töflu 5). Eini pátturinn sem gaf vísbendingar um tengsl var аð að einstaklingar sem voru ekki að vinna eða voru í starfi ótengdu námi voru síður líklegir en peir sem voru leiðbeinendur í grunnskóla til að falla í flokkinn háir á kvarðanum yfir aðdráttarafl kennslu.

Tafla 5. Dátttakendur sem eru háir og lágir á kvarðanum yfir aðdráttarafl kennslustarfsins, skoðaðir eftir bakgrunnspáttum, hlutfalli og líkindahlutfalli.

\begin{tabular}{|c|c|c|c|c|c|c|c|c|}
\hline \multirow{3}{*}{ Allir } & \multicolumn{2}{|c|}{ Lágir } & \multicolumn{2}{|c|}{ Háir } & \multirow{3}{*}{ OR } & \multirow{2}{*}{\multicolumn{2}{|c|}{ 95-ÖB }} & \multirow{3}{*}{$\mathbf{p}$} \\
\hline & \multirow{2}{*}{$\begin{array}{c}\% \\
54,4\end{array}$} & \multirow{2}{*}{$\begin{array}{c}\mathbf{n} / \mathbf{N} \\
112 / 206\end{array}$} & \multirow{2}{*}{45,6} & \multirow{2}{*}{$\begin{array}{c}\mathbf{n} / \mathbf{N} \\
94 / 206\end{array}$} & & & & \\
\hline & & & & & & & & \\
\hline Móðir með háskólapróf & & & & & & & & \\
\hline Já & 54,5 & $42 / 77$ & 45,5 & $35 / 47$ & 1 & & & \\
\hline $\mathrm{Nei}$ & 54,1 & $60 / 111$ & 45,9 & $51 / 11$ & 1,020 & 0,569 & 1,828 & 0,947 \\
\hline Faðir með háskólapróf & & & & & & & & \\
\hline Já & 46,6 & $27 / 58$ & 53,4 & $31 / 58$ & 1 & & & \\
\hline Nei & 58,0 & $76 / 131$ & 42,0 & $55 / 131$ & 0,630 & 0,338 & 1,174 & 0,146 \\
\hline Foreldri/foreldrar kennarar & & & & & & & & \\
\hline Já & 46,8 & $22 / 47$ & 53,2 & $25 / 47$ & 1 & & & \\
\hline Nei & 57,3 & $83 / 143$ & 42,7 & $61 / 143$ & 0,655 & 0,338 & 1,269 & 0,210 \\
\hline Námsform & & & & & & & & \\
\hline Fjarnám & 55,6 & $35 / 63$ & 44,4 & $28 / 63$ & 1 & & & \\
\hline Вæði stað- og fjarnám & 62,2 & $23 / 37$ & 37,8 & $14 / 37$ & 0,761 & 0,332 & 1,744 & 0,519 \\
\hline Staðnám & 50,0 & $44 / 88$ & 50,0 & $44 / 88$ & 1,250 & 0,653 & 2,393 & 0,501 \\
\hline Vinnutími & & & & & & & & \\
\hline 0-10 klst. & 60,0 & $45 / 75$ & 40,0 & $30 / 75$ & 1 & & & \\
\hline $11-30$ klst. & 47,4 & $36 / 76$ & 52,6 & $40 / 76$ & 1,667 & 0,874 & 3,177 & 0,121 \\
\hline 31 klst. eða meira & 58,3 & $21 / 36$ & 41,7 & $15 / 36$ & 1,071 & 0,478 & 2,403 & 0,867 \\
\hline Starf & & & & & & & & \\
\hline Leiðbeinandi í grunnskóla & 33,3 & $6 / 18$ & 66,7 & $12 / 18$ & 1 & & & \\
\hline $\begin{array}{l}\text { Starf ótengt námi eða } \\
\text { vinn ekki }\end{array}$ & 58,6 & $58 / 99$ & 41,4 & $41 / 99$ & 0,353 & 0,123 & 1,019 & 0,054 \\
\hline Starf tengt námi & 53,5 & $102 / 188$ & 46,5 & $86 / 188$ & 0,434 & 0,147 & 1,285 & 0,132 \\
\hline
\end{tabular}

Dar sem pessar niðurstöður bentu til pess að ekki væri hægt að skýra aðdráttarafl kennarastarfsins nema að litlu leyti með páttum sem tilgreindir eru í töflu 4 var skoðað hvernig reynsla í náminu, bæði af fræðilegum hluta námsins og einnig af vettvangsnámi og samstarfi við æfingakennara, hefði áhrif á pað hvort pátttakendur féllu í hópinn sem var hár eða hópinn sem var lægri á pættinum. Í ljós komu jákvæð tengsl við alla pætti, sterkust við samræður við æfingakennara, en líkurnar á pví að einstaklingar væru háir á kvarðanum sem mælir aðdráttarafl kennslu jukust um 1,804 fyrir hvert eitt stig sem einstaklingar voru hærri á peim kvarða (sjá nánar töflu 6). 
Tafla 6. Meðaltal, staðalfrávik og hlutfallslíkindi á páttum í námi pátttakenda eftir pví hvort peir eru lágir eða háir á kvarðanum yfir aðdráttarafl kennarastarfsins.

\begin{tabular}{lcccccccccc}
\hline & \multicolumn{3}{c}{ Lágir } & \multicolumn{1}{c}{ Háir } & & & & \\
& M & sf & N & M & sf & N & OR & $95-O ̈ B$ & p \\
\hline Uppeldis- og kennslufræði & 3,9 & 1,4 & 100 & 4,8 & 1,4 & 89 & 1,620 & 1,289 & 2,035 & $<0,001$ \\
Kennslufræði greina & 4,1 & 1,4 & 100 & 5,0 & 1,4 & 90 & 1,605 & 1,283 & 2,006 & $<0,001$ \\
Samræður við æfingakennara & 4,5 & 1,3 & 103 & 5,4 & 1,2 & 90 & 1,804 & 1,399 & 2,326 & $<0,001$ \\
$\begin{array}{l}\text { Hæfni æfingakennara við að } \\
\text { tengja saman fræði og starf }\end{array}$ & 2,9 & 1,5 & 101 & 4,2 & 1,6 & 90 & 1,678 & 1,364 & 2,063 & $<0,001$ \\
$\begin{array}{l}\text { Endurgjöf og leiðsögn frá } \\
\text { æfingakennurum }\end{array}$ & 5,1 & 1,3 & 100 & 5,9 & 1,2 & 89 & 1,687 & 1,292 & 2,202 & $<0,001$ \\
\hline
\end{tabular}

Í töflu 7 eru prjú líkön notuð til að skýra breytileika í aðdráttarafli kennarastarfsins. Líkan 1 með páttum um uppeldis- og kennslufræði og kennslufræði greina skýrði 16\% breytileikans. Líkan 2 með páttunum samræður við æfingakennara, hæfni æfingakennara við að tengja saman fræði og starf og endurgjöf og leiðsögn frá æfingakennurum skýrir 24,5\% af breytileikanum. Dar var einn páttur sem var tölfræðilega marktækur pegar tekið hafði verið tillit til annarra pátta ílíkaninu en pað var hæfni æfingakennara til að tengja saman fræði og starf. Loks skýra allir pessir pættir ef peir eru settir inn í líkan um leið $32 \%$ af breytileikanum.

Tafla 7. Aðhvarfsgreining hlutfalla, samanburður ólíkra líkana sem skýra aðdráttarafl kennarastarfsins.

\begin{tabular}{|c|c|c|c|c|c|c|c|c|c|}
\hline & \multicolumn{3}{|c|}{ Líkan 1} & \multicolumn{3}{|c|}{ Líkan 2} & \multicolumn{3}{|c|}{ Líkan 3} \\
\hline & $B$ & S.E & $O R$ & $B$ & S.E & $O R$ & $B$ & S.E. & $O R$ \\
\hline Uppeldis- og kennslufræði & 0,259 & 0,178 & 1,296 & & & & 0,132 & 0,203 & 1,098 \\
\hline Kennslufræði greina & 0,310 & 0,178 & 1,363 & & & & 0,387 & 0,160 & 1,243 \\
\hline Samræður við æfingakennara & & & & 0,187 & 0,176 & 1,205 & 0,271 & 0,185 & 1,141 \\
\hline $\begin{array}{l}\text { Hæfni æfingakennara við að } \\
\text { tengja saman fræði og starf }\end{array}$ & & & & 0,395 & 0,137 & $1,484 * *$ & 0,093 & 0,219 & $1,473 *$ \\
\hline $\begin{array}{l}\text { Endurgjöf og leiðsögn frá } \\
\text { æfingakennurum }\end{array}$ & & & & 0,256 & 0,168 & 1,292 & 0,218 & 0,215 & 1,311 \\
\hline Nagelkerke R Square & & 0,160 & & & 0,245 & & & 0,320 & \\
\hline
\end{tabular}

\section{Umræða}

Degar fjallað er um kennaranám parf að muna að í yfir tuttugu ár hefur verið hægt að stunda pað bæði í fjarnámi og staðnámi við Menntavísindasvið HÍ og við Háskólann á Akureyri. Upp úr aldamótunum varð inntaka í fjarnám óhád reynslu af kennslu og síðan hafa hópar fjarnema og staðnema við Kennaraháskólann, síðar Menntavísindasvið, verið álíka stórir (Kennaraháskóli Íslands, 2003, 2008). Frá og með haustinu 2010 var hætt að skrá nema eftir námsformum (Háskóli Íslands, e.d.) og eftir pað er pví byggt á ýmsum könnunum par sem nemar eru beðnir að skilgreina námsform sitt. Í könnun sem lögð var fyrir leik- og grunnskólakennaranema skólaárið 2010-2011 sögðust um 43\% vera í fjarnámi, um 35\% í staðnámi og 22\% ýmist í stað- eða fjarnámi (Duríður Jóhannsdóttir og Sólveig Jakobsdóttir, 2011). Í peirri könnun sem hér er kynnt og var lögð fyrir á vormisseri 2017 voru 34\% svarenda fjarnemar, tæp 47\% staðnemar en tæp 20\% sögðust 
taka námskeið bæði í stað- og fjarnámi. Dað er mikilvægt fyrir skipulag kennaranáms að vita hvort pessir hópar fjarnema, staðnema og peirra sem taka námskeið bæði í stað- og fjarnámi séu ólíkir og fyrri rannsóknarspurningin beindist að pví. Niðurstöðurnar leiða í ljós að staðnemar og fjarnemar í grunnskólakennaranámi við Menntavísindasvið eru ólíkir hópar en mikilvægt er að átta sig á sérstöðu hvers hóps um sig ef ætlunin er að stuðla að pví að fleiri ljúki námi innan eðlilegra tímamarka.

Rannsóknir benda til pess að stór hluti peirra sem ljúka kennaranámi hefji aldrei störf við kennslu, eða 35\%, og að tæp 30\% peirra sem hefja kennslu hverfi frá henni á fyrstu árunum. Einnig hefur komið fram að fari kennarar ekki að starfa við kennslu á fyrstu fimm árum eftir útskrift er ólíklegt að peir snúi sér að kennslu (Helgi Eiríkur Eyjólfsson, 2017; Helgi Eiríkur Eyjólfsson og Stefán Hrafn Jónsson, 2017). Dað er pví mikilvægt að vita hvaða pættir stuðla að pví að kennaranemum pyki kennarastarfið eftirsóknarvert, en pað eykur líkur á að peir fari að kenna.

Fyrri rannsóknir hafa sýnt að íslenskir kennaranemar í fjarnámi eru yfirleitt eldri en staðnemar (Ríkisendurskoðun, 2003, Sólveig Jakobsdóttir o.fl., 2008). Dessi rannsókn leiðir í ljós pað sem ekki hefur komið fram áđur, að pjóðfélagslegur bakgrunnur pessara hópa er ólíkur. Erlendar rannsóknir sýna sambærilegar niðurstöður um pjóðfélagslegan bakgrunn fjarnema í háskólanámi (Bailey o.fl., 2018). Fjarnemar voru líklegri en staðnemar til að eiga foreldra með stutta skólagöngu, pannig var líklegra að mæður fjarnema væru einungis með grunnskólapróf og ólíklegra að foreldrar peirra væru með háskólapróf. Staðnemar voru hins vegar líklegri til að eiga foreldra sem voru kennarar. Fyrir fjarnema má pví ætla að kennaramenntun sé leið til að bæta pjóðfélagsstöðu sína með aukinni menntun á meðan næstum priðjungur staðnema fetar í fótspor foreldranna og gerist kennari.

Degar kemur að atvinnupátttöku kennaranema kemur í ljós að rúmlega 70\% í öllum hópunum vinna með fram náminu og sést að hlutfall staðnema sem vinna hefur hækkað frá 2004 (Amalía Björnsdóttir, 2009). Fjarnemar skera sig pó áberandi frá hinum hópunum par sem $42 \%$ peirra unnu meira en 30 klst. á viku. Staðnemar unnu mun minna, en tæpur helmingur peirra vann 10 klst. eða minna og aðeins 4,5\% peirra unnu meira en 30 klst. Hópurinn sem var ýmist í staðeða fjarnámi er parna á milli en samt nær staðnemahópnum, pó að hann vinni aðeins meira, en tæp 14\% sögðust vinna meira en 30 klst. á viku. Vegna mikillar vinnu má leiða líkur að pví að námsframvinda fjarnema sé töluvert hægari en staðnema. Í háskólanámi er gert ráo fyrir 44 til 53 vinnustundum nemenda á viku (Baldur Sigurðsson, 2011). Sé kennaranemi að vinna 31 klst. á viku pá er vinnutími hans í fullu námi og starfi 75 klst. á viku, sem er óraunhæft. Líklegt er pví að stór hluti nema sem vinna petta mikið, sem eru rúm 40\% fjarnema og $20 \%$ allra kennaranema, taki námið á lengri tíma en fimm árum.

Sá hópur sem tekur námskeið ýmist í stað- eða fjarnámi er miklu minni en hinir en pað getur verið hagræði að pví að hafa pennan kost, bæði fyrir Menntavísindasvið og kennaranema. Mörg námskeið í framhaldsnámi eru einungis boðin í fjarnámi með staðlotum og fámenn námskeið eru oft kennd í pví formi í grunnnámi líka til að ná upp í viðurkennda hópastærð (Sólveig Jakobsdóttir o.fl., 2008). Nemum kann að pykja pægilegt að geta tekið námskeið í fjarnámi til að geta haldið áfram námi pó að aðstæður breytist, t.d. vegna flutninga, barneigna eða annars sem kemur í veg fyrir að peir geti mætt í skóla. Dar sem fjarnemar eru margir í mjög mikilli vinnu eða kjósa fjarnám vegna búsetu er ólíklegra að peir hafi aðstæður til að taka stök námskeið í staðnámi. Dess vegna má líta svo á að pó að í stórum dráttum sé um tvo hópa að ræða, p.e. staðnema og fjarnema, pá sé mikilvægt að vita hver sé sérstaða pess hóps sem tekur námskeið ýmist í stað- eða fjarnámi (Bailey o.fl., 2018) og almennt parf að vera ljóst hvernig mismunandi aðstæður hópanna kalla á ólíkan stuðning við námsframvindu.

Fyrstu árin sem kennaranám var í bođi í fjarnámi var gert rád fyrir að flestir fjarnemar tækju námið með kennslu sem leiðbeinendur í skólum. Eftir að fjarnámið var opnað fyrir fleirum upp úr aldamótum var stór hluti fjarnema pó áfram við kennslu. Um aldamótin voru $72 \%$ leik- og 
grunnskólakennaranema í fjarnámi leiðbeinendur í skólum (Auður Kristinsdóttir o.fl., 2001) og árið 2004 voru 42\% fjarnema í grunnskólakennaranámi leiðbeinendur (Amalía Björnsdóttir, 2009). Síðustu ár hefur kennaraskortur ekki verið jafn mikið vandamál og var áður og pví kemur ekki á óvart að hlutfallslega færri voru við störf sem leiðbeinendur árið 2017, en pá voru 20\% fjarnema leiðbeinendur í grunnskólum. Par sem vitað er að nokkur hluti meistaranema í grunnskólakennaranámi starfar við kennslu með fram náminu pyrfti að fylgjast með pví hversu hátt hlutfall leiðbeinenda er með B.Ed-próf í grunnskólakennarafræðum.

Rannsóknir hafa sýnt að reynsla af kennslu hefur jákvæð áhrif á trú kennaranema á eigin getu (Humprey o.fl., 2008). Um 40\% allra svarenda sögðust vera í starfi sem tengdist náminu, svo sem 1 frístundastarfi, að vinna sem leiðbeinandi í leikskóla, við ípróttapjálfun eða starfa með fötluðum. Sé leiðbeinendum bætt við var um helmingur í starfi tengdu náminu en helmingur í ótengdu starfi. Ætla mætti að reynsla af tengdum störfum hefði jákvæð áhrif á pað hvort pátttakendum í könnuninni pætti kennarastarfið eftirsóknarvert. Í ljós kom að peir sem störfuðu sem leiðbeinendur voru líklegri til að telja kennarastarfið eftirsóknarvert en peir sem voru ekki að vinna eða voru í starfi ótengdu námi. Dættir í bakgrunni kennaranema, svo sem menntun foreldra og hvort peir væru í staðnámi eða fjarnámi, tengdust pví ekki hversu eftirsóknarvert peim fannst kennarastarfið. Dví hefur stundum verið haldið fram að fjarnemar séu líklegri til að vilja fara í kennslu og að peir endist fremur í kennslustörfum (Hrólfur Kjartansson o.fl., 1999) en niðurstöður okkar sýna ekki fram á að svo sé, heldur að pað séu starfandi leiðbeinendur sem vilji frekar fara 1 kennslu, en peir voru hærra hlutfall fjarnema á árum ádur, eins og fyrr segir.

Kannað var hvernig reynsla í kennaranáminu, bæði af fræðilegum hluta námsins og einnig af vettvangsnámi og samstarfi við æfingakennara, hefði áhrif á pað hversu eftirsóknarvert kennaranemum fyndist kennarastarfið. Spurt var um gagnsemi námskeiða í almennri kennslufræði annars vegar og kennslufræði greina hins vegar, til að mynda hvort par væru gefin raunveruleg dæmi og hvort tenging við kennarastarfið væri skýr. Í tengslum við vettvangsnámið var spurt um samræður við æfingakennara, endurgjöf og leiðsögn frá peim og hæfni æfingakennara til að tengja saman fræði og starf. Í ljós komu jákvæð tengsl við alla pætti. Sterkust reyndust tengslin vera við samræður við æfingakennara. Deir pættir sem tengjast vettvangsnámi voru hærri en uppeldis- og kennslufræðipættirnir. Dessar niðurstöður sýna vel hversu mikilvægt starf leiðsagnarkennara 1 vettvangsnámi er par sem samræður kennaranema og vettvangsnema geta ráðið miklu um pað hvort kennaranemar fara að kenna, og er petta í samræmi við niðurstöður Humprey o.fl. (2008) og Duríðar Jóhannsdóttur (2012, 2015) um mikilvægi vettvangsskólanna fyrir kennaranema. Ekki skal samt gera lítið úr áhrifum námskeiðanna í kennslufræði; pau skipta miklu máli, og kennslufræði greina skorar heldur hærra.

Samtals skýra pættirnir sem tengjast uppeldis- og kennslufræði og kennslufræði greina 16\% af breytileika í pættinum sem mælir hversu eftirsóknarvert kennarastarfið pykir en pættir tengdir æfingakennslu og samstarfi við æfingakennara skýra 25\%. Dessi pættir skarast pó og saman skýra peir $32 \%$ af breytileikanum. Pegar allir pættir eru settir saman í líkan til að skýra breytileika í kennarastarfinu er einn einstakur páttur marktækur pegar búið er að taka tillit til hinna, en pað er hæfni æfingakennarans til að tengja saman fræði og starf. Sá páttur var reyndar lægstur pegar hver páttur var skoðaður fyrir sig og reynsla nema af honum var breytilegri en af öðrum páttum sem spurt var um. Detta bendir til pess að hann mæli nokkuð sem er sérstakt og kannski eitthvað sem við purfum sérstaklega að huga að til að byggja upp öflugt kennaranám sem skilar kennurum til starfa.

Niðurstöður pessarar rannsóknar eru mikilvægur liður í að kanna ólíka stöðu kennaranema við Menntavísindasvið eftir pví hvort peir hafa valið að stunda námið í hefðbundnu staðnámi eða fjarnámi eða taka námskeið í stað- eða fjarnámi eftir hentugleikum. Starfshópur á vegum Menntamálaráðuneytisins sem í eiga sæti fulltrúar kennarasamtaka, sveitarfélaga og háskóla sem mennta kennara hefur lagt fram tillögur til að bæta nýliðun í stétt kennara (leik-, grunnog framhaldsskólakennara). Í tillögu rýnihópsins sem lögð var fram í júní 2018 (Sigurður 
Sigurjónsson, 2018) er gert ráð fyrir að síðasta árið í fimm ára kennaranámi verði skipulagt að meginhluta sem vettvangsnám par sem kennaranemar starfi sem kennarakandídatar í skólum. Pá er mikilvægt að taka mið af pví sem erlendar jafnt og íslenskar rannsóknarniðurstöður benda til, að val á skóla og leiðsagnarkennurum í vettvangsnámi sé líklegt til að hafa áhrif á gæði kennaranámsins og jafnframt pað hvort kennaranemar velja að starfa sem kennarar að loknu námi (Humprey o.fl., 2008; Duríður Jóna Jóhannsdóttir, 2010).

Möguleikar pess að próa frekar fjarnám til að mæta vandanum við að fjölga kennurum hafa lítið eða ekkert verið til umræðu í pessu sambandi en í ljósi erlendra rannsókna og reynslu og rannsókna á kennaramenntun á Íslandi má ætla að pað sé pess virði að próa nýjar leiðir í fjarnámi kennaranema. Hugsanlega er litið svo á að fjarnám sé pegar í boði par sem pað er nemum í sjálfsvald sett hvort peir taka námskeiðin í staðnámi eða fjarnámi. Prátt fyrir pað gerir núverandi skipulag ráð fyrir að kennaranám sé fimm ár, burtséð frá pví hvaða námsform er valið, en námshraðinn er síðan á ábyrgð hvers og eins. Ekki er gert ráð fyrir neinum sérstökum úrræðum eða stuðningi við fjarnema, sem gera má ráð fyrir að taki námið á töluvert lengri tíma en staðnemar, miðað við hvað peir vinna mikið. Ekki er heldur gert ráð fyrir að skipulag náms og kennslu sé öðruvísi fyrir pá kennaranema sem vinna sem leiðbeinendur í skólum. Pegar hæg námsframvinda er áhyggjuefni er mikilvægt að greina á milli ólíkra aðstæðna fjarnema og staðnema og próa viðeigandi stuðning til að fjölga peim sem ljúka kennaranámi. Ef ætlun er að útskrifa fleiri kennara parf að taka mið af pví að um helmingur kennaranema tekur námið í fjarnámi meðfram töluvert mikilli vinnu. Skipulag námsins parf að taka mið af pessu og velta má fyrir sér hvort pörf sé á ólíkum leiðum annars vegar fyrir staðnema og hins vegar fyrir fjarnema. Niðurstöður pessarar rannsóknar benda einnig til pess að gæði bæði fræðilegs náms og vettvangsnáms hafi áhrif á pað hversu fýsilegt nemum finnst kennarastarfið og par með líkurnar á pví að peir fari að kenna og endist í kennslu.

\section{On-campus and distance students inthe compulsory teacher education program at the University of Iceland School of Education: Background, attitudes and commitment to the teaching profession}

In Iceland, 5 years of university education are required to qualify as a compulsory school teacher. Teacher education is offered at the University of Iceland (UI) in Reykjavík, and at the University of Akureyri in North Iceland. The focus of this article is compulsory teacher education at the University of Iceland. Student teachers can choose between campus-based attendance and online learning with required periodical face-to-face sessions, and can even choose which form they prefer in each individual course. Around half of the students at UI are online students.

In Iceland, like in many other countries, declining enrollment in teacher education programs has caused concern about the shortage of qualified teachers at the compulsory school level. In the 1990s, a similar situation was met by a special effort to enable universities to enroll more student teachers and to offer distance education for teachers without formal qualifications who were teaching in rural schools. As a result, the percentage of uncertified teachers decreased (especially in rural areas) and, when an economic crisis hit Iceland in 2008, teachers returned to work in compulsory schools, increasing the number of qualified teachers. However, in 2015 the number of teachers without certification started to increase once again, from 4\% on average from 2011 to 2014 to 9\% in 2017. The ratio of individuals dropping out from compulsory teacher education, as well as from the profession, also causes concern. Therefore, it is important to investigate which factors might be related to student teachers' commitment to the teaching profession. Because teacher education 
at the University of Iceland has been offered both on-campus and as a blend of online and face-to-face, we think it is of particular interest to understand whether there is a difference between students in online and on-campus programs.

This study presents a picture of the background of students in the teacher education program at the University of Iceland School of Education, and explores whether there are differences between distance and on-campus students. We are looking at students' work experience, hours worked per week, their parents' education, and how those factors relate to their commitment to the teaching profession. We also investigate the potential relevance of the following aspects to students' commitment to the teaching profession: pedagogy, subject-didactics, communication with practice mentors, mentor skills in relating theory and praxis, and feedback and discussion with practice mentors.

The data was derived from an online questionnaire administered in the spring of 2017 at the University of Iceland School of Education. All participants were students ( $\mathrm{N}=$ 208) in a five-year teacher education program, training to be teachers in compulsory schools in Iceland. The data was collected online.

$87 \%$ of participants were female. $33 \%$ were online students, $47 \%$ were on campus, and $20 \%$ of students took classes both on campus and online. $47 \%$ of on-campus students had a mother with a university education; the same was true for $29 \%$ of students in the distance education program and $49 \%$ of students that took classes in both forms. $35 \%$ of students in the distance program had a mother with only compulsory education compared to $19 \%$ of the on-campus students and $27 \%$ of those taking classes both on campus and online. About $13 \%$ of distance students, $41 \%$ of on-campus students, and $35 \%$ of students choosing both forms had a father with a university education. Around $16 \%$ of students in the distance education program had a parent who was a teacher, compared to $31 \%$ of the students in the on-campus program.

Around $30 \%$ of participants were not working, and the percentage was similar for distance, on campus, and students taking both classes online and on campus. $20 \%$ of online students were working as teachers in compulsory schools without the proper qualifications, compared to $2 \%$ of on-campus students and $8 \%$ of students taking both forms. Of the distance students, $48 \%$ were either not working or working in a field unrelated to their studies. The same was true for $55 \%$ of on-campus students and $54 \%$ of students in both programs. $42 \%$ of students in the distance programs worked more than 30 hours per week; only $5 \%$ of on campus students put in that many hours.

The study found no difference in the commitment to the teaching profession between online and on-campus students, but did find a higher level of commitment among students working as teachers. Satisfaction with relevance of pedagogy and subjectdidactics correlates with commitment levels; however, there is a stronger correlation with factors relevant to practice teaching. This aligns with previous studies that have shown the importance of practice schools in educating teachers.

Keywords: teacher education, distance teacher education, on-campus teacher education, attraction of the teaching profession, compulsory teacher education 


\section{Um höfundana}

Duríður Jóna Jóhannsdóttir (thuridur@hi.is) er dósent í menntunarfræðum við Menntavísindasvið Háskóla Íslands og umsjónarmaður í Menntun framhaldsskólakennara. Hún lauk B.A.-prófi í íslensku og pjóðfélagsfræði frá HÍ árið 1978, prófi í uppeldis- og kennslufræði til kennsluréttinda 1990, M.Ed-prófi frá Kennaraháskóla Íslands 2001 og doktorsprófi frá HÍ 2010. Rannsóknir hennar hafa snúist um fjarnám í kennaranámi og á framhaldsskólastigi, notkun upplýsingatækni í skólum, próun framhaldsskóla, nám á landsbyggðinni og námskrárpróun.

Amalía Björnsdóttir (amaliabj@hi.is) er prófessor við deild Heilsueflingar, íprótta- og tómstunda á Menntavísindasviði Háskóla Íslands. Hún lauk B.A.-prófi í sálfræði frá Háskóla Íslands árið 1991, M.Sc.prófi frá University of Oklahoma 1994 og doktorsprófi frá sama skóla 1996. Hún hefur lagt stund á rannsóknir á sviði mælinga og prófagerðar, lestrar- og málproskamælinga, skólastjórnunar og áhrifa félagslegra pátta á skólastarf.

\section{About the authors}

Thurídur Jóna Jóhannsdóttir (thuridur@hi.is) is an Associate Professor in Educational Studies at the School of Education, University of Iceland and programme coordinator in Pedagogy for upper secondary teachers. She completed her B.A. degree in Icelandic and sociology in 1978, and a postgraduate teaching certificate diploma in 1990 at the University of Iceland, an M.Ed degree in pedagogy in 2001 at the Iceland University of Education, and a PhD in educational studies in 2010 at the University of Iceland. Her research areas include online learning, teacher education, ICT in education, upper secondary education, rural education and curriculum development

Amalía Björnsdóttir (amaliabj@hi.is) is a professor at Faculty of Health Promotion, Sport and Leisure Studies at the School of Education, University of Iceland. She completed a B.A. degree in psychology from the University of Iceland in 1991, and a Ph.D. from the University of Oklahoma in 1996. Her major research interests are in the areas of measurement and testing (reading and language development), school management and impacts of social factors on education.

\section{Heimildir}

Amalía Björnsdóttir. (2009). Fjarnemar og staðnemar árið 2004 [óútgefið handrit].

Auður Kristinsdóttir, Ásrún Matthíasdóttir og M. Allyson Macdonald. (2001). Úttekt á fjarkennslu við Kennaraháskóla Íslands. Sótt af https://notendur.hi.is/allyson/fjarkennslasskyrslanetutgafa.pdf

Bailey, A., Henry, N., Laverdiere, R. og Pugliese, L. (2018). Making digital learning work. Success strategies from six leading universities and community colleges. Sótt af https://edplus.asu.edu/what-we-do/making-digital-learning-work

Baldur Sigurðsson. (2011). Mæling náms í ektum - undirstaða gæðastarfs? Rádstefnurit Netlu - Menntakvika 2011. Sótt af http://netla.hi.is/menntakvika2011/alm/002.pdf

Bragi Guðmundsson. (2016, 26. október). Nokkrar tölur um kennaradeild HA, aðsókn og útgefin leyfisbréf [erindi á málpinginu KÍ til forystu: forystufræðsla fyrir forystusveit KÍ og aðildarfélaga og starfsmenn KÍ. Reykjavík]. Sótt af http://ki.is/images/Skrar/KI/Fraedslumal/2016/14110216_Forystufraedsla_HA.pdf

Christophersen, K.-A., Elstad, E., Solhaug,T. og Turmo,A. (2016). Antecedents of student teachers' affective commitment to the teaching profession and turnover intention. European Journal Of Teacher Education, 39(3), 270-286. doi:10.10 80/02619768.2016.1170803

Christophersen, K.-A., Elstad, E., Juuti, K., Solhaug,T. og Turmo,A. (2017). Duration of on-campus academic engagements of student teachers in Finland and Norway. Education Inquiry, 8(2), 89-103. doi:10.1080/20004508.2016.1275194

Hagstofa Íslands. (2018a). Kennurum án kennsluréttinda fjölgar í grunnskólum. Sótt af https://hagstofa.is/utgafur/ frettasafn/menntun/grunnskolar-haustid-2017/

Hagstofa Íslands. (2018b). Starfsfólk við kennslu eftir kyni, aldri og réttindum 1998-2017. Sótt af https://hagstofa.is/ talnaefni/samfelag/menntun/grunnskolastig/

Hagstofa Íslands. (2018c). Starfsfólk við kennslu eftir kyni, landsvæðum og kennsluréttindum 1998-2017. Sótt af https:// hagstofa.is/talnaefni/samfelag/menntun/grunnskolastig/ 
Hagstofa Íslands. (2018d). Brautskráningar á háskólastigi og doktorsstigi eftir einstöku sviði, prófgráðu og kyni 19952016. Sótt af https://hagstofa.is/talnaefni/samfelag/menntun/haskolastig/

Háskóli Íslands (e.d.). Háskólinn í tölum, Nemendur. Sótt af https://www.hi.is/kynningarefni/nemendur

Helgi Eiríkur Eyjólfsson. (2017).Tímaatburðagreining á ferli nýútskrifaðra grunnskólakennara (óutgefin meistararitgerð). Sótt af http://hdl.handle.net/1946/29028

Helgi Eiríkur Eyjólfsson og Stefán Hrafn Jónsson. (2017). Skýrsla til starfshóps um nýliðun og bætt starfsumhverfi grunnskólakennara í Reykjavík. Könnun á meðal útskriftaárganga úr kennaranámi HÍ/KHÍ og HA árin 2000-2012. Reykjavík: Rannsóknarsetur í mannfjöldafræðum.

Hrólfur Kjartansson, Eiríkur Kjartansson, Tómas Ingi Olrich, Sigrún Magnúsdóttir, Guðrún Ebba Ólafsdóttir, Ólafur H. Jóhannsson, . . Marta Hreiðarsdóttir. (1999). Mat á kennarapörf í grunnskólum fram til ársins 2010. Sótt af http:// archive.is $/ 2 \mathrm{e} 0 \mathrm{aB}$

Humprey, D. C., Wechsler, M. E. og Hough, H. J. (2008). Characteristics of effective alternative teacher certification programs. Teachers College Record, 110(1), 1-63.

Jón Jónasson. (2001). On-line distance education: a feasible choice in teacher education in Iceland? (óutgefin meistararitgerð). Sótt af https://jonjonassonnet.files.wordpress.com/2018/02/thesis

Juuti, K., Christophersen, K.-A., Elstad, E., Solhaug, T. og Turmo, A. (2018). Finnish teacher education and its contributions to pre-service teachers' instructional self-efficacy. Issues in Educational Research, 28(2), 422-437. Sótt af http:// www.iier.org.au/iier28/juuti.pdf

Kennslan gekk vonum framar. (1996, 24. ágúst). Morgunblaðið. Sótt af https://www.mbl.is/greinasafn/grein/282987/

Kennaraháskóli Íslands. (2003). Kennaraháskóli Íslands - Ársskýrsla 2002. Reykjavík: Höfundur.

Kennaraháskóli Íslands. (2008). Kennaraháskóli Íslands - Ársskýrsla 2007. Reykjavík: Höfundur.

Lára Stefánsdóttir og Sigurjón Mýrdal. (1993). Fjarkennsla um tölvunet. Uppeldi og menntun, 2, 121-130.

Lög um menntun og ráđningu kennara og skólastjórnenda við leikskóla, grunnskóla og framhaldsskóla nr. 87/2008.

OECD. (2014). TALIS 2013 results: An international perspective on teaching and learning. doi:10.1787/9789264196261-en

OECD. (2018). Effective teacher policies: Insights from PISA. doi:10.1787/9789264301603-en

Petersen, D. (2010). Rekrutteringsproblematikken på de nordiske lareruddannelser. doi:10.6027/TN2010-533

Rasmussen, J. og Dorf, H. (2010). Challenges to Nordic teacher education programmes. Í B. Hudson, P. Zgaga og B. Åstrand (ritstjórar), Advancing quality cultures for teacher education in Europe. Tensions and opportunities (bls. 51-68). Umeå: Umeå University.

Ríkisendurskoðun. (2003). Grunnskólakennarar Fjöldi og menntun Stjórnsýsluúttekt. Sótt af https://rikisendurskodun.is/ wp-content/uploads/2016/01/kennarar.pdf

Ríkisendurskoðun. (2017). Kostnaður og skilvirkni kennaramenntunar. Háskóli Íslands og Háskólinn á Akureyri. Reykjavík: Höfundur.

Robinson, B. og Latchem, C. (2003). Open and distance teacher education. Uses and models. Í B. Robinson og C. Latchem (ritstjórar), Teacher education through open and distance learning (bls. 28-47). London: RoutledgeFalmer.

Sahlberg, P. (2017). Finnska leiðin 2.0. Hvað getur umheimurinn laert af breytingum í finnska skólakerfinu? (Sigrún Á. Eiríksdóttir pýddi). Reykjavík: Félag grunnskólakennara.

Schwille, J. og Dembélé, M. (2007). Global perspectives on teacher learning: Improving policy and practice. Sótt af https://publications.iiep.unesco.org/Global-perspectives-teacher-learning-improving-policy-practice

Sigríður Sigurjónsdóttir og Anna Kristín Sigurðardóttir. (2017). Viðhorf brautskráðra leik- og grunnskólakennara til námsins og starfsins. Niðurstöður úr símakönnun. Áfangaskýrrla. Sótt af https://www.hi.is/sites/default/files/ingunney/skjol/afangaskyrsla_vidhorf_brautskradra_leik__og_grunnskolakennara.pdfhttps://www.hi.is/sites/default/files/ ingunney/skjol/afangaskyrsla_vidhorf_brautskradra_leik__og_grunnskolakennara.pdf

Sigurður Sigurjónsson. (2018, 2. júlí) Núverandi staða. Kennarasamband Íslands. Sótt af http://ki.is/pistlar/4816-stad-ansvipud-ef-ekki-verri

Sólveig Jakobsdóttir, Elsa Sigríður Jónsdóttir, Hanna Lilja Valsdóttir, Ingibjörg B. Frímannsdóttir og Duríður Jóhannsdóttir. (2008). Fjarnám við Kennaraháskóla Íslands: Skipulag á staðlotum og leiðir til að draga úr brottfalli. Sótt af https://geymsla. hi.is/f/87091b427e/

Duríður Jóna Jóhannsdóttir. (2010). Teacher education and school-based distance learning: Individual and systemic development in schools and a teacher education programme (óutgefin doktorsritgerð). Sótt af http://hdl.handle.net/1946/7119

Duríður Jóhannsdóttir. (2012) Að læra að verða kennari í starfi á vettvangi. Netla sérrit - Veftímarit um uppeldi og menntun. Sótt af http://netla.hi.is/greinar/2012/ryn/003.pdf 
Duríður Jóhannsdóttir. (2013). „What we wanted to do was to change the situation“: Distance teacher education as stimulation for school development in Iceland. Netla - Veftímarit um uppeldi og menntun. Sótt af http://netla.hi.is/ greinar/2013/ryn/010.pdf2012

Duríður Jóhannsdóttir. (2015). Responsive practices in online teacher education. ÍT. Hansson (ritstjóri), Contemporary approaches to activity theory: Interdisciplinary perspectives on human behavior (bls. 1-18). doi:10.4018/978-1-4666-6603-0.ch001

puríður Jóhannsdóttir. (2016, 26. október). Tölur um aðsókn og fjölda brautskráðra á Menntavísindasviði Háskóla Íslands [Erindi á málpinginu KÍ til forystu: forystufræðsla fyrir forystusveit KÍ og aðildarfélaga og starfsmenn KÍ. Reykjavík]. Sótt af http://ki.is/images/Skrar/KI/Fraedslumal/2016/08112016_Forystufraedsla_MVS_HI.pdf

Duríður Jóhannsdóttir og Roth, W.-M. (2014). Experiencing (Pereživanie) as developmental category: Learning from a fisherman who is becoming (as) a teacher-in-a-village-school. Outlines. Critical Practice Studies, 15(3), 54-78. Sótt af https://tidsskrift.dk/outlines/article/view/19861

Duríður Jóhannsdóttir og Sólveig Jakobsdóttir. (2011). Samkennsla staðnema og fjarnema við Menntavísindasvið Háskóla Íslands. Reynsla og viðhorf kennara og nema - togstreita og tækifæri. Ráðstefnurit Netlu - Menntakvika 2011. Sótt af http://netla.hi.is/menntakvika2011/033.pdf

Duríður Jóna Jóhannsdóttir og Amalía Björnsdóttir (2018).

Staðnemar og fjarnemar í grunnskólakennaranámi við Menntavísindasvið: Bakgrunnur, viðhorf og áhugi á að starfa við kennslu.

Netla - Veftímarit um uppeldi og menntun. Menntavísindasvið Háskóla Íslands.

Sótt af http://netla.hi.is/greinar/2018/ryn/11

DOI: https://doi.org/10.24270/netla.2018.11 